\title{
Urbanization, Slums, and the Carbon Intensity of Well-being: Implications for Sustainable Development
}

\author{
Jennifer E. Givens \\ Department of Sociology, \\ Washington State University, Pullman, United States
}

\section{Abstract}

Previous research in macro comparative environmental sociology analyzes both environmental and human well-being outcomes of urbanization. The carbon intensity of well-being (CIWB) concept simultaneously measures environmental and human well-being. Here I ask how various types of urbanization, an underexplored concept in the CIWB research, contributes differently to the CIWB of nations. Using longitudinal two-way fixed effects Prais-Winsten regression models for the years 1990-2011 for 78 countries, I find that level of development and urbanization are associated with higher CIWB, as are the percentage of urban populations with access to improved water and sanitation; conversely, urban slum prevalence is associated with lower CIWB. Comparing more versus less developed countries, I find the results are especially robust for lower-income countries. I also find that overall population access to water and sanitation is associated with lower CIWB. The findings suggest directions for sustainable development that take into account different forms of urbanization and both rural and urban population well-being.

Keywords: urbanization, slum, well-being, carbon, development, environment

\section{Introduction}

Urbanization is a global trend; however, in different contexts urbanization takes contrasting forms. Urban slums are a particular type of urbanization that is of concern to scholars interested in development, human well-being, and the environment (UN-HABITAT, 2012). Davis (2007) draws attention to the massive growth of urban slums and the development and sustainability challenges they present, and scholarly research analyzes both the human and environmental outcomes of slum growth (Jorgenson \& Rice, 2010; Jorgenson, Rice, \& Clark, 2010, 2012; Rice, 2008). Liu et al. (2007, p. 644) write, “although development- 
as-usual has initial economic benefit, traditional development strategies need to be altered, and transforming them into sustainable practices is urgent ... In the transition to sustainability, those not yet enjoying the fruits of development need help." Scholars have long recognized that if the less developed nations follow the development trajectories of the more developed nations it will be unsustainable on a planetary scale, and yet not meeting the well-being needs of the poor or calling nations with low $\mathrm{CO}_{2}$ emission but with low population well-being "sustainable" is inaccurate and unjust.

The carbon intensity of well-being (CIWB) is a concept that enables a crossnational assessment of sustainable development by combining an environmental and human well-being measure into one indicator (Dietz, Rosa, \& York, 2009, 2012; Jorgenson, 2014, 2015; Jorgenson \& Dietz, 2015; Jorgenson \& Givens, 2015). Countries with low emissions but low well-being and countries with high well-being but high emissions both have high CIWB, which is undesirable. Countries with low emissions but high well-being have low CIWB. An effective sustainability strategy includes reducing the CIWB (Jorgenson, 2014).

Focusing on equitable and green urban development is a key area for improvement in lowering the CIWB. Thus, in this paper I examine the varied effects of urbanization and urban slum growth on the CIWB. This work builds on the tradition of research that examines the effects of population dynamics in conjunction with affluence as a driver of environmental impacts and with the general body of macro-comparative quantitative work that examines humanenvironment relationships (Dietz \& Jorgenson, 2013).

In what follows, I first review current information on urbanization trends and slums. I then discuss previous sociological research on the relationships between urbanization, slums, development, human well-being, and the environment. Next I describe the CIWB concept and literature. After a discussion of data, methods, and results, I conclude with some implications of the findings for sustainable development and suggestions for future research.

\section{Urbanization and slums}

As of 2008, half of the world's population was urban and the world continues to urbanize, with six out of 10 people expected to reside in urban areas by 2030 (UN-HABITAT, 2015b). Globally, however, urbanization occurs differently and takes different forms. Continued urbanization is occurring slowly in the more developed countries (MDCs), adding about six million people per year (UN-HABITAT, 2012), while more than $90 \%$ of the growth in urban areas will take place in Africa, Asia, Latin America, and the Caribbean (UN-HABITAT, 2015b). 
This contributes to the fact that the population of less developed countries (LDCs), as opposed to MDCs, accounts for $82 \%$ of world population. Half of the world's urban population lives in Asia. Latin America and the Caribbean are the most urban regions of the world at $80 \%$ urban, compared to Europe which is $73 \%$ urban; Africa is the least urban, but African countries have some of the largest urban growth rates (UN-HABITAT, 2012).

In some cities the proportion of residents who live in slums is as high as $80 \%$ (UN-HABITAT, 2015a). Although the percent of the urban population living in slums has declined since 1990 for most regions, raw numbers of slum dwellers are increasing (UN-HABITAT, 2012). Since 2000, the global slum population has risen by 55 million (UN-HABITAT, 2015a). Although the pace of urban population growth in LDCs has slowed from about $3 \%$ to $2.4 \%$ as of 2010 , this is still 3.5 times higher than the annual average population growth rate in MDCs. In developing countries, slum prevalence is highest in Sub-Saharan Africa, with $62 \%$ of the urban population living in slums, and lowest in North Africa (13\%), and it is $25 \%$ in Western Asia, 35\% in South Asia, and $24 \%$ in Latin America and the Caribbean (UN-HABITAT, 2012). In terms of raw numbers, Sub-Saharan Africa has a slum population of 199.5 million, South Asia 190.7 million, East Asia 189.6 million, Latin America and the Caribbean 110.7 million, Southeast Asia 88.9 million, West Asia 35 million and North Africa 11.8 million (UN-HABITAT, 2015a).

Slums present a variety of social and environmental problems. The United Nations Human Settlements Programme (UN-HABITAT) defines a slum household as a group of individuals living under the same roof in an urban area who lack one or more of the following five conditions: (1) durable housing of a permanent nature that protects against extreme climate conditions; (2) sufficient living space which means no more than three people sharing the same room; (3) easy access to safe water in sufficient amounts at an affordable price; (4) access to adequate sanitation in the form of a private or public toilet shared by a reasonable number of people; and (5) security of tenure that prevents forced evictions. In addition, 30-40\% of non-permanent houses in the cities of less developed countries are located in areas prone to floods, landslides, hurricanes, and earthquakes. All slums are not the same, nor do all slum residents suffer the same degree of deprivation, as some may meet only one of the conditions while others may have all five. Slum residents are the most deprived in SubSaharan Africa (UN-HABITAT, 2006). As poverty is urbanized and patterns of settlement are established that are difficult to alter, these circumstances structure ongoing problems, and high rates of poverty and prevalence of slums impede the prosperity of cities (UN-HABITAT, 2012, p. 99). Slum dwellers are also often stigmatized and face discrimination. UN-HABITAT warns that "highly unequal cities are a ticking time bomb waiting to explode (UN-HABITAT, 2012, p. 95) 
and that some cities are expanding in an unplanned and low density way that is not sustainable (UN-HABITAT, 2012, p. 28). UN-HABITAT (2012, p. 117) also states, "During the last two decades, the pitfalls of the conventional urban development model have become more glaring."

Addressing human and environmental issues related to urbanization and slums is an important sustainable development issue, and various groups work to improve the situations in slums. UN-HABITAT assists national programs by providing capital and technical assistance in the areas of productivity, infrastructure, quality of life, equity, and environmental sustainability, and the interdependencies and interactions among these. While the Millennium Development Goals focused on human well-being and sustainability, the post-2015 Sustainable Development Goals also add a specific goal focused on the sustainability of cities (Sachs, 2015). Amnesty International sponsors a radio project in Ghana and Kenya that aims to challenge negative perceptions of slum inhabitants by providing a way for them to tell their stories to the wider population (Amnesty International, 2012). Slum Dwellers International is a ground-up organization/global social movement that aims for solidarity among the global poor and provides structures for networking and programs such as community investment saving groups for women. High-density living may be more sustainable than other forms of urbanization if population needs can be met.

\section{Research on urbanization, slums, development, and the environment}

Scholars have observed and examined the increasing urbanization of the planet for decades, and comparative international sociologists study both the drivers and the consequences of this phenomenon. Early works focused both on internal dynamics within countries, such as rural push and urban pull factors (Firebaugh, 1979), and on external characteristics of the world system, such as dependency on foreign direct investment in structuring urban change, especially in less developed countries (Kentor, 1981; Timberlake \& Kentor, 1983). While the former research focusing on dynamics within the nation-state is based on traditional modernization or ecological theory, the latter research drawing attention to forces external to the nation-state, such as the penetration of global capitalism, comes from political economy (Kasarda \& Crenshaw, 1991; London, 1987). London (1987) highlights that the political economy perspective perceives push-pull internal dynamics, such as the commercialization of agrarian production, in addition to urbanization itself, as shaped by international forces, and he concludes that forces both internal and external to the nation-state must be considered to conduct a complete analysis of urban change. Furthermore, 
urban growth is a product of both domestic and international migration, natural population growth of urban populations is affected by the fact that migration age often coincides with fertility, and boundary changes occur, thus necessitating going beyond simply looking at internal rural/urban push-pull factors (Kasarda \& Crenshaw, 1991; London, 1987; Smith \& London, 1990).

Urbanization occurred first in what are now the more developed countries and some therefore assume that what is currently occurring in less developed countries is a similar pathway to development; this view is in line with assumptions of modernization theory regarding development (Smith, 1996). However, the scale at which urbanization is occurring in less developed countries today is much larger (Kasarda \& Crenshaw, 1991; Preston, 1979). Two explanations for this difference are that (1) natural population increase was lower when today's more developed countries were experiencing their urbanization, and (2) that the global context differed, for example in terms of the landscape of competition and in terms of colonial migration as an alternative to urban migration (Kasarda \& Crenshaw, 1991; Massey, 1988; Williamson, 1988). Today there are vast inequalities in development and cities in LDCs (Evans \& Timberlake, 1980; Kentor, 1981; Molotch, 1976). While urbanization may lead to economic development, the benefits often accrue unevenly, going disproportionately to international interests and domestic elites (Chase-Dunn, 1975; Rice \& Rice, 2012). Current research examines debt dependence and how it increases the portion of the total population living in urban slums (Davis, 2007; Rice, 2008; Rice \& Rice, 2012). The growth and scale of urban slums is therefore more accurately considered a development challenge rather than a natural occurrence in the course of development.

Current macro comparative research looks at the impacts of different forms of urbanization, including slums, on both human and environmental well-being. Rice (2008) proposes that the presence of urban slums affects population level measures of well-being including infant and under-five mortality, maternal mortality, and life expectancy. Also, Rice (2008) attributes the urbanization of poverty trend to a continuation of dependency relations in the world economy. This work calls into question the assumption that urban residents in general have better access to health resources, suggesting instead that urban residents of slums may suffer an urban penalty that is detectable at the national level. Slum proliferation indicates that attention should be paid to the development and path dependency of the construction of the built environment, how context matters for well-being outcomes, and the social causes of disease (Rice \& Rice, 2009). Several empirical studies test and find support for the assertion that urban slum prevalence has negative impacts on population level measures of well-being while noting that more macro comparative work should attend to nuanced and uneven manifestations of urbanization (Jorgenson \& Rice, 2010), 
as there is evidence of temporal and regional variation (Jorgenson, Rice, \& Clark, 2012). In terms of the relationship between slums and the environment, while urbanization is found to increase energy consumption, urban slum prevalence is associated with a decrease in energy consumption (Jorgenson, Rice, \& Clark, 2010). Urbanization in general has a positive effect on $\mathrm{CO}_{2}$ emissions, although this varies by level of development and region, and it changes in magnitude over time (Jorgenson, Auerbach, \& Clark, 2014). In related literature, scholars assess whether rural environmental degradation and other related quality of life issues act as push factors contributing to high rates of urbanization in LDCs (Moriniere, 2012; Sanderson, 2009; Shandra, London, \& Williamson, 2003) and examine the loss of arable land to urban and slum expansion (Fazal, 2000; Liu, Wang, \& Long, 2009).

\section{The carbon intensity of well-being (CIWB)}

In their study on urbanization, slums, and energy consumption, Jorgenson, Rice, and Clark (2010, p. 193) note that energy consumption "underlies an improved quality of life." The CIWB gets directly at the relationship between emissions and quality of life. The CIWB and related concepts offer a way to assess sustainability by combining human and environmental components into one measure and capturing the relationship between human well-being and the stress humans, often in the pursuit of well-being, can put on the environment (Dietz, Rosa, \& York, 2009, 2012). In an article seen as foundational to this area of research, Mazur and Rosa (1974) ask if massive energy consumption is necessary to maintain current living standards in the U.S., since other countries use less energy but maintain comparable living standards. While they find a high correlation between energy consumption and lifestyle when examining a global sample of countries, when they limit the sample to developed countries many of the correlations are no longer significant. Continuing this line of inquiry, Mazur (2011) finds a lack of association between energy consumption and improvements in quality of life over the past 30 years in developed nations. Dietz, Rosa, and York $(2009,2012$, p. 26) are the first to create and use a measure that represents how efficiently a nation is producing well-being for its citizens, calling it a "foray into this reformulation of development" and analyzing the relationship between environmentally efficient well-being and economic growth. Others analyze the relationship between economic growth and the energy efficiency of well-being (Jorgenson, Alekseyko, \& Giedraitis, 2014); ecological intensity of well-being (Jorgenson \& Dietz, 2015); the environmental intensity of well-being using a subjective measure of well-being (Knight \& Rosa, 2011); and the carbon intensity of well-being (Jorgenson, 2014; Jorgenson \& Givens, 2015). The CIWB is a ratio of $\mathrm{CO}_{2}$ emissions to a measure of well-being that is comparable cross 
nationally (usually life expectancy). Thus, nations with relatively higher CIWBs have either high life expectancy but high emissions, or low life expectancy and low emissions. Nations with low CIWBs have relatively higher life expectancies with relatively lower levels of emissions.

A related body of work also examines the relationship between human needs and environmental impact and directly informs this research. Steinberger and Roberts (2010) find evidence in some contexts that energy use and carbon emissions are decoupling from human needs at higher levels of consumption and income, and that past a certain point increasing energy consumption or carbon emissions does not have major advantages in terms of progress on well-being. This is in line with earlier findings from Mazur and Rosa (1974; see also Mazur, 2011). This research draws upon Goldemberg et al. (1985) and the concept of a threshold of necessary energy consumption and develops the concept of "Goldemberg-Corner countries," which have relatively high life expectancies but with relatively low $\mathrm{CO}_{2}$ emissions compared to countries with similar life expectancies. The presence of these Goldemberg countries shows that the high levels of emissions of some of the MDCs are not necessary to reach high levels of human well-being, and suggest alternative pathways to and conceptions of sustainable development. This research also examines the impact of affluence on increasing $\mathrm{CO}_{2}$ emissions beyond sustainable levels (Steinberger et al., 2012) and other cross-national drivers in an effort to gain a better understanding of a new class of "sustainability states" (Lamb et al., 2014, p. 7).

\section{The analyses}

This study builds upon research, reviewed above, that finds generally that urbanization is associated with increases in both $\mathrm{CO}_{2}$ emissions and life expectancy, while urban slums tend to decrease $\mathrm{CO}_{2}$ emissions and life expectancy. This study aims to assess the effects of different forms of urbanization on the CIWB of nations. I test the following two hypotheses:

Hypothesis 1: Urbanization will be associated with an increase in the CIWB of nations.

Hypothesis 2: Urban slum prevalence will be associated with a decrease in the CIWB of nations. 
The data are for a sample of 78 countries with yearly data from 1990 to $2011 .^{1}$ Countries included in the analyses that have the highest CIWBs include Bahrain, Rwanda, Zambia, South Africa, the United States, and Nigeria. Those with the lowest CIWBs, the Goldemberg countries, include Costa Rica, Vietnam, Panama, Uruguay, Sri Lanka, and Ecuador (see Lamb et al., 2014 for a visual depiction of CIWB country distribution). I estimate models for the entire sample of 78 countries and also for a split sample of 26 more developed countries (MDCs) and 52 less developed countries (LDCs). I also estimate a model with more control variables for a sample of 46 LDCs; the sample is reduced because there are missing data for some of the additional variables.

\section{Dependent variable}

The dependent variable, the CIWB, is a ratio between carbon emissions and life expectancy. This is the same ratio used in previous studies (e.g., Jorgenson, 2014). The data for the $\mathrm{CO}_{2}$ emissions are from the CAIT 2.0 climate data explorer (World Resources Institute, accessed August 2, 2014). The $\mathrm{CO}_{2}$ emissions data are provided in millions of metric tons, therefore I used population data from the World Bank (World Bank World Development Indicators, accessed July 24, 2014) to convert total emissions data into per capita measures in metric tons. The well-being measure, life expectancy, comes from the same World Bank source and is also per capita. Life expectancy is total life expectancy at birth, or the total number of years an infant would be expected to live if patterns of mortality at the time of its birth remained the same throughout its life.

The CIWB is a ratio. In order for the numerator or the denominator to not have a disproportionate influence, I take the same approach as previous research (Dietz, Rosa, \& York, 2012; Jorgenson, 2014; Jorgenson \& Givens, 2015) and constrain the coefficients of variation, the standard deviation over the mean, to be equal by adding a constant to the $\mathrm{CO}_{2}$ measure, shifting the mean without changing the variance. I multiply by 100 to scale the ratio.

$\mathrm{CIWB}=\left[\left(\mathrm{CO}_{2} \mathrm{pc}+28\right) / \mathrm{LE}\right]^{*} 100$

\footnotetext{
1 Countries included in the analyses: MDCs: Australia, Austria, Bahrain, Canada, Chile, Denmark, Finland, France, Germany, Greece, Ireland, Israel, Japan, S. Korea, Netherlands, Norway, Oman, Portugal, Saudi Arabia, Singapore, Spain, Sweden, Switzerland, United Kingdom, United States, Uruguay; LDCs: Bangladesh, Benin, Bolivia, Brazil*, Bulgaria*, Cameroon, China*, Colombia, Costa Rica, Cote d'Ivoire, Ecuador, Egypt, El Salvador, Ethiopia, Ghana, Guatemala, Guinea, Honduras, Hungary*, India, Indonesia, Kenya, Lao PDR, Madagascar, Malawi, Malaysia, Mauritius, Mexico, Morocco, Mozambique, Nepal, Nicaragua, Nigeria, Pakistan, Panama, Peru, Philippines, Romania*, Rwanda, Senegal, South Africa, Sri Lanka, Tanzania, Thailand, Togo, Tunisia, Turkey*, Uganda, Venezuela, Vietnam, Zambia, Zimbabwe ( ${ }^{*}$ indicates missing from model 4).
} 


\section{Independent variables}

The independent variables all come from the World Bank (World Bank World Development Indicators, accessed July 24, 2014). I control for level of economic development as GDP per capita in constant 2005 U.S. dollars. ${ }^{2}$ Level of development is the variable that most research in this area has examined (e.g., Jorgenson, 2014). I also control for exports as a percent of GDP, which represents the value of all goods and other market services provided outside the nation-state and is commonly included as a measure of connection to the global economy (Rosa \& Dietz, 2012).

The first independent variable of interest is the measure of urbanization, urban population as a percent of total population. ${ }^{3}$ The second variable of interest is the percent of the urban population with access to an improved water source and the third is the percent of the urban population with access to improved sanitation facilities. The fourth variable of interest is the percent of the total population with access to an improved water source and the fifth is the percent of the total population with access to improved sanitation facilities. In additional analyses, I also control for two other variables that are expected to have a detectable effect on overall population health and $\mathrm{CO}_{2}$ emissions: the total fertility rate and the prevalence of HIV, measured as the prevalence of HIV in the population ages 15-49 (Jorgenson \& Rice, forthcoming).

While previous research has used the UN-HABITAT provided measure of a slum (e.g., Jorgenson et al., 2010; Jorgenson et al., 2012; Rice \& Rice, 2009, 2012), I instead use two separate measures that focus on access to water and access to sanitation facilities. These World Bank data have better coverage of a greater number of countries, are comparable across both urban and overall population settings, and are the two that are arguably most directly linked to health and well-being. Also, lack of access to an improved water source and sanitation facility are the most common indicators of urban slum residence in the developing countries (Rice, 2008; UN-HABITAT, 2003). Furthermore, access to water and sanitation have historically been key parts of development; in addition to being basic needs, providing access requires not only the work of individuals and households but also collective systems, whether public, private, or a combination, to establish and maintain infrastructure. The two slum indicators used here are correlated at .66. See Table 1 for descriptive statistics and correlations.

2 According to the data source dollar figures for GDP are converted from domestic currencies using 2005 official exchange rates.

3 According to the data source these data are based on national definitions of what constitutes rural versus urban, and while this means that cross-national comparisons may need to be made with caution, allowing for this variation arguably allows for a more accurate assessment of what constitutes rural versus urban in a particular country. 


\begin{tabular}{|c|c|c|c|c|c|c|c|c|c|c|c|c|c|c|c|c|c|c|c|c|c|c|}
\hline & & & & & & & & & & & & $\sigma$ & & & & & & & & & & $\begin{array}{l}8 \\
\text { O } \\
0\end{array}$ \\
\hline & & & & & & & & & & & & $\infty$ & & & & & & & & & $\begin{array}{l}\widetilde{N} \\
\varnothing \\
\infty \\
0 \\
\end{array}$ & $\begin{array}{l}\overline{5} \\
\text { m } \\
0\end{array}$ \\
\hline & & & & & & & & & & & & $\wedge$ & & & & & & & & $\begin{array}{l}\text { Oू } \\
\infty \\
0 \\
0\end{array}$ & $\begin{array}{l}2 \\
0 \\
0 \\
0 \\
0\end{array}$ & 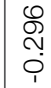 \\
\hline & & & & & & & & & & & & 0 & & & & & & & 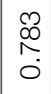 & $\begin{array}{l}0 \\
\stackrel{8}{2} \\
0 \\
0\end{array}$ & 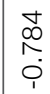 & 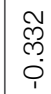 \\
\hline & $\begin{array}{l}\mathscr{\varrho} \\
\varrho \\
\varrho \\
\dot{\sigma}\end{array}$ & 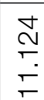 & $\begin{array}{l}\text { ग্ } \\
\stackrel{5}{\circ}\end{array}$ & 우 & 8 & 8 & $\$$ & & 8 & $\stackrel{\leftrightarrow}{\wedge}$ & 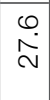 & 10 & & & & & & $\begin{array}{l}\hat{0} \\
0 \\
0 \\
0\end{array}$ & \begin{tabular}{|l}
10 \\
0 \\
0 \\
0
\end{tabular} & $\begin{array}{l}0 \\
0 \\
0 \\
0\end{array}$ & $\begin{array}{l}0 \\
0 \\
0 \\
0 \\
0\end{array}$ & $\begin{array}{l}0 \\
0 \\
0 \\
0\end{array}$ \\
\hline & $\begin{array}{l}\bar{\sigma} \\
\dot{\infty} \\
\end{array}$ & $\begin{array}{l}\hat{\kappa} \\
\dot{\gamma}\end{array}$ & $\begin{array}{l}\mathscr{\varrho} \\
\stackrel{\oplus}{\leftarrow}\end{array}$ & $\stackrel{\nabla}{\circ}$ & $\stackrel{3}{\stackrel{0}{R}}$ & $\begin{array}{l}0 \\
\infty\end{array}$ & ? & & $\stackrel{\vec{v}}{\mathrm{v}}$ & 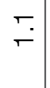 & $\check{0}$ & $\nabla$ & & & & & $\stackrel{50}{\stackrel{5}{0}}$ & $\begin{array}{l}0 \\
8 \\
0 \\
0\end{array}$ & $\begin{array}{l}\bar{\tau} \\
0 \\
0\end{array}$ & $\begin{array}{l}0 \\
0 \\
0 \\
0\end{array}$ & $\begin{array}{l}\infty \\
0 \\
0 \\
0 \\
0\end{array}$ & 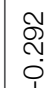 \\
\hline & 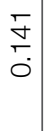 & $\underset{r}{\stackrel{O}{\tau}}$ & $\begin{array}{l}0 \\
D \\
0 \\
0\end{array}$ & 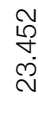 & $\begin{array}{l}\infty \\
\infty \\
0 \\
0\end{array}$ & $\frac{d}{\Delta}$ & $\begin{array}{ll}5 \\
7\end{array}$ & 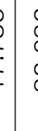 & 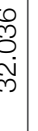 & $\begin{array}{l}\stackrel{Q}{ } \\
\notin \\
-\end{array}$ & $\begin{array}{l}\widehat{N} \\
0 \\
\dot{+}\end{array}$ & m & & & & $\begin{array}{l}\text { N్} \\
\text { } \\
0\end{array}$ & 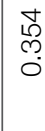 & $\begin{array}{c}\text { N } \\
\text { N } \\
0 \\
0\end{array}$ & $\begin{array}{l}\infty \\
0 \\
0 \\
0 \\
0\end{array}$ & 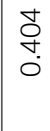 & 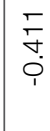 & $\begin{array}{l}\widetilde{N} \\
\tilde{0} \\
0 \\
0\end{array}$ \\
\hline & $\begin{array}{l}0 \\
\mathbb{0} \\
\infty \\
\dot{c}\end{array}$ & $\frac{\mathbb{N}}{\infty}$ & 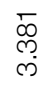 & $\begin{array}{l}\mathbb{N} \\
0 \\
0 \\
\varnothing\end{array}$ & $\begin{array}{l}\llcorner \\
\stackrel{0}{0} \\
\stackrel{0}{0}\end{array}$ & 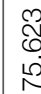 & $\xi_{\delta}$ & $\begin{array}{l}j \\
\vdots \\
\vdots \\
\vdots\end{array}$ & 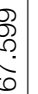 & $\begin{array}{l}\infty \\
\stackrel{\infty}{\infty} \\
\dot{m}\end{array}$ & 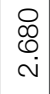 & $\sim$ & & & $\begin{array}{l}\stackrel{P}{+} \\
\stackrel{0}{0}\end{array}$ & 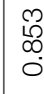 & \begin{tabular}{|l}
0 \\
0 \\
0 \\
0 \\
0
\end{tabular} & $\begin{array}{l}\tau \\
\sigma \\
0 \\
0\end{array}$ & $\begin{array}{l}8 \\
\text { 9 } \\
0\end{array}$ & $\begin{array}{l}\widetilde{N} \\
0 \\
0 \\
0 \\
0\end{array}$ & $\begin{array}{l}\text { 足 } \\
\stackrel{2}{0} \\
0\end{array}$ & $\begin{array}{l}8 \\
\text { N } \\
\text { ? }\end{array}$ \\
\hline & $\begin{array}{l}\mathcal{N} \\
\infty \\
\sim \\
\Gamma\end{array}$ & 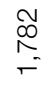 & 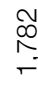 & 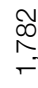 & $\stackrel{+}{\stackrel{2}{N}}$ & N & i & $=$ & 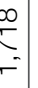 & $\begin{array}{l}\bar{\infty} \\
\stackrel{1}{\sim} \\
\Gamma^{-}\end{array}$ & $\begin{array}{l}0 \\
\mathscr{\delta} \\
\stackrel{-}{-}\end{array}$ & $\tau$ & & $\begin{array}{l}0 \\
0 \\
0 \\
0 \\
1\end{array}$ & $\begin{array}{l}\text { N్ } \\
\text { N̦ } \\
\text { i }\end{array}$ & $\begin{array}{l}\text { J } \\
\stackrel{f}{*}\end{array}$ & 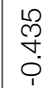 & $\begin{array}{l}\hat{\alpha} \\
0 \\
0 \\
0\end{array}$ & $\begin{array}{l}8 \\
0 \\
0 \\
0\end{array}$ & $\begin{array}{l}\infty \\
0 \\
0 \\
0\end{array}$ & $\begin{array}{l}\text { ㅁ } \\
\stackrel{1}{0} \\
\text {. }\end{array}$ & $\begin{array}{l}\widehat{o} \\
0 \\
0 \\
0\end{array}$ \\
\hline & 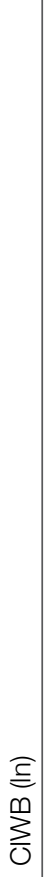 & 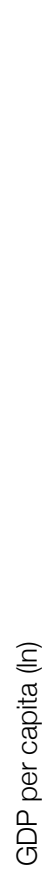 & 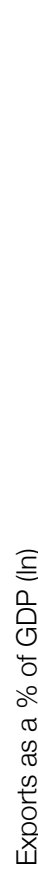 & 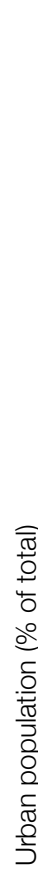 & 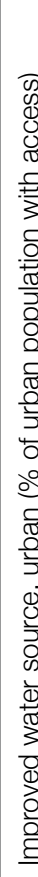 & 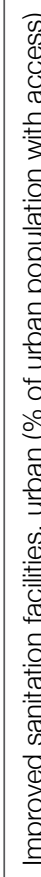 & , & 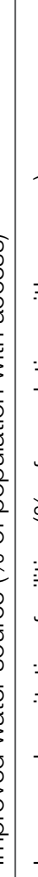 & 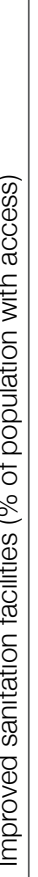 & 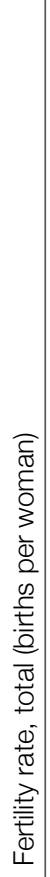 & 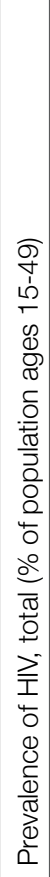 & & 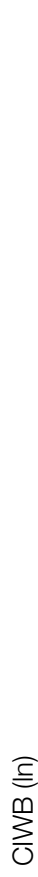 & 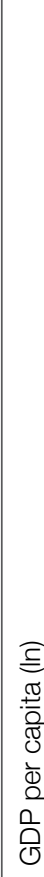 & 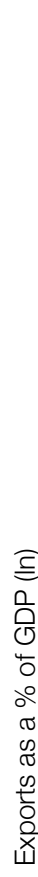 & 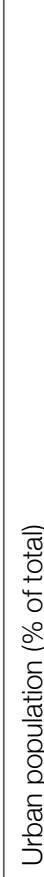 & 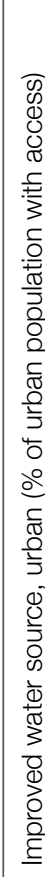 & 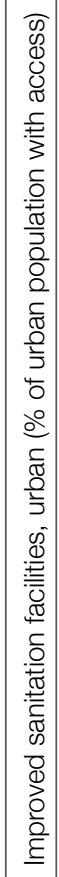 & 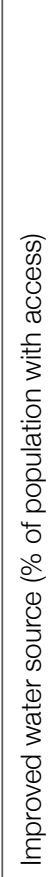 & 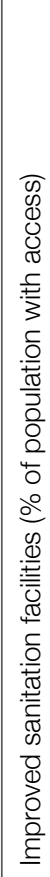 & 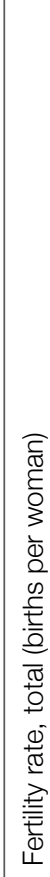 & 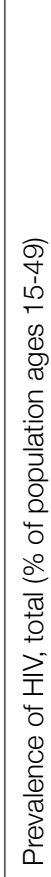 \\
\hline & - & $N$ & ल & $\nabla$ & ما & $c$ & 1 & & $\infty$ & $\infty$ & 으 & & - & $\sim$ & ल & $\nabla$ & م & 0 & $\wedge$ & $\infty$ & $\infty$ & 으 \\
\hline
\end{tabular}




\section{Model estimation technique}

I estimate Prais-Winsten models with panel-corrected standard errors (PCSE). This is an appropriate method for dealing with comparative international time series cross-sectional data where data often have the structure of 10 to 100 units observed over 20 to 50 years, and where errors may be serially (i.e., temporally) correlated, spatially (i.e., contemporaneously) correlated, and characterized by heteroscedasticity (all the error processes may not have the same variance) (Beck \& Katz, 1995). The method suggested by Beck and Katz (1995) and employed here retains OLS parameter estimates but uses panel corrected standard errors, which deal with spatial correlation and heteroscedasticity, while the Prais-Winsten transformation corrects for ARl/serial correlation.

I include country-specific and year-specific intercepts, making the model equivalent to a two-way fixed effects model. As with a fixed effects model, this technique estimates effects within countries (rather than between countries) over time and controls for variation between countries. This model construction is especially well-suited to hypothesis testing as it controls for all period-specific and country-specific variation. For this reason most models are parsimonious and only control for level of development, level of economic integration, and the key population measures related to urbanization or well-being.

\section{Results}

Table 2 presents the findings for the analyses. Model 1 contains all 78 countries included in the analyses and controls for the following: GDP per capita, logged to address positive skew; exports as a percent of GDP, also logged; urban population as a percent of the total population; the percent of the urban population with access to an improved water source; the percent of the urban population with access to improved sanitation facilities; the percent of the total population with access to an improved water source; and the percent of the total population with access to improved sanitation facilities. Model 2 presents the results for these same variables on a subset of 26 more developed countries (MDCs) and model 3 presents these analyses on the remaining 52 less developed countries (LDCs). Model 4 includes two additional control variables expected to have population well-being and environmental effects: the total fertility rate and the prevalence of HIV in the population of 15-49 year olds. For each model I report regression coefficients, significance level, panel corrected standard errors, R-squared statistic, the number of countries included, the number of observations, and the minimum observations per country. The high R-squared statistics are common for this methodological approach to analyzing longitudinal data that includes unreported unit and year specific intercepts (Jorgenson, 2011; Jorgenson \& Givens, 2015). While the data 
set is unbalanced, meaning there are missing values, the data are mostly complete with the minimum observations per country not falling lower than 18 out of a possible 22 for the years 1990-2011. Although models with variables added incrementally are not reported, results are substantively similar. Results of these sensitivity analyses are available upon request.

Table 2. Predictors of the carbon intensity of well-being (CIWB) for high (HIC) and non-high (non-HIC) income countries: Results from two-way fixed effects Prais-Winsten regression models, 1990-2011

\begin{tabular}{|c|c|c|c|c|}
\hline & $\begin{array}{l}\text { Model } 1 \\
\text { All }\end{array}$ & $\begin{array}{l}\text { Model } 2 \\
\text { MDC }\end{array}$ & $\begin{array}{l}\text { Model } 3 \\
\text { LDC }\end{array}$ & $\begin{array}{l}\text { Model } 4 \\
\text { LDC }\end{array}$ \\
\hline \multirow[t]{2}{*}{ GDP per capita (In) } & $0.049^{\star \star \star}$ & $0.163^{\star \star \star}$ & $0.036^{*}$ & 0.017 \\
\hline & $(0.014)$ & $(0.019)$ & $(0.017)$ & $(0.017)$ \\
\hline \multirow[t]{2}{*}{ Exports as a \% of GDP (In) } & $-0.009^{\star \star}$ & 0.010 & $-0.007^{\star}$ & $-0.009^{*}$ \\
\hline & $(0.003)$ & $(0.008)$ & $(0.004)$ & $(0.004)$ \\
\hline \multirow[t]{2}{*}{ Urban population (\% of total) } & $0.001^{*}$ & $0.002^{\star *}$ & 0.000 & $-0.002^{*}$ \\
\hline & $(0.000)$ & $(0.001)$ & $(0.001)$ & $(0.001)$ \\
\hline \multirow{2}{*}{$\begin{array}{l}\text { Improved water source, urban (\% of urban } \\
\text { population with access) }\end{array}$} & $0.008^{\star \star \star}$ & $0.021^{\star \star \star}$ & $0.007^{\star \star \star}$ & $0.008^{\star \star \star}$ \\
\hline & $(0.001)$ & $(0.004)$ & $(0.001)$ & $(0.001)$ \\
\hline \multirow{2}{*}{$\begin{array}{l}\text { Improved sanitation facilities, urban (\% of } \\
\text { urban population with access) }\end{array}$} & $0.008^{\star * *}$ & $-0.009^{\star *}$ & $0.009^{\star \star *}$ & $0.008^{\star \star \star}$ \\
\hline & $(0.001)$ & $(0.003)$ & $(0.001)$ & $(0.001)$ \\
\hline \multirow{2}{*}{$\begin{array}{l}\text { Improved water source (\% of population } \\
\text { with access) }\end{array}$} & $-0.005^{\star \star \star}$ & $-0.009^{\star *}$ & $-0.005^{\star \star \star}$ & $-0.005^{\star \star \star}$ \\
\hline & $(0.001)$ & $(0.003)$ & $(0.001)$ & $(0.001)$ \\
\hline \multirow{2}{*}{$\begin{array}{l}\text { Improved sanitation facilities (\% of population } \\
\text { with access) }\end{array}$} & $-0.005^{\star \star \star}$ & $0.012^{\star \star \star}$ & $-0.006^{\star \star \star}$ & $-0.005^{\star \star \star}$ \\
\hline & $(0.001)$ & $(0.003)$ & $(0.001)$ & $(0.001)$ \\
\hline \multirow[t]{2}{*}{ Fertility rate, total (births per woman) } & & & & $0.013^{\star}$ \\
\hline & & & & $(0.005)$ \\
\hline \multirow{2}{*}{$\begin{array}{l}\text { Prevalence of HIV, total (\% of population } \\
\text { ages 15-49) }\end{array}$} & & & & $0.012^{\star \star \star}$ \\
\hline & & & & $(0.002)$ \\
\hline R-squared & 0.9981 & 0.9987 & 0.9981 & 0.9983 \\
\hline Number of countries & 78 & 26 & 52 & 46 \\
\hline Number of observations & 1704 & 571 & 1133 & 1004 \\
\hline Minimum observations per country & 18 & 21 & 18 & 18 \\
\hline
\end{tabular}

Notes: ${ }^{\star} \mathrm{p}<.05,{ }^{\star \star} \mathrm{p}<.01,{ }^{\star \star \star} \mathrm{p}<.001$; panel-corrected standard errors in parentheses

In models 1, 2, and 3, GDP per capita, the indicator for level of development, is positive and significant in the total sample of countries and in the subsets of more and less developed countries. Positive and significant GDP per capita is associated with increasing CIWB, which is undesirable for sustainability. GDP per capita is not significant in model 4 on the reduced sample of 46 LDCs, which also controls for fertility rate and HIV prevalence. Exports as a percent of GDP, the indicator for 
connection to the world economy, is significant for the total sample of countries and in both analyses of LDCs. Urban population is positive and significant for the total sample and for the MDCs, non-significant for the LDCs, and weakly negative in model 4 on the reduced sample of LDCs. These findings are in line with the assertion that urbanization varies in different contexts.

In terms of the findings of specific interest, urban population access to an improved water source has consistently positive and significant effects across all four models, and urban population access to improved sanitation is also positive and significant in models 1,3 , and 4 . These variables were retained in the form of urban population access to mirror the variables that indicate total population access; however, creating a slum measure by subtracting the urban percent with access yields results with the same coefficients but a sign change, meaning urban slum presence has a negative effect on the CIWB.

Conversely, total population access to an improved water source is consistently negative and significant across all four models, and total population access to improved sanitation is negative and significant in models 1, 3, and 4. In model 2, the analysis on 26 MDCs, there is a finding counter to the rest of the analyses that urban access to improved sanitation has a negative effect on the CIWB and total population access to improved sanitation has a positive effect on the CIWB, however, making too much of these findings should be avoided for two reasons: the small sample and, more importantly, the low amount of variation for these variables within the sample of 26 MDCs over the time period analyzed. While urban access to water and sanitation varies from $70.3 \%$ to $100 \%$ and $8.6 \%$ to $100 \%$, respectively, in the total sample, the variation is only from $83.4 \%$ to $100 \%$ and $91.3 \%$ to $100 \%$, respectively, for MDCs. Likewise, the total population access to water and sanitation varies from $13.2 \%$ to $100 \%$ and $2.4 \%$ to $100 \%$, respectively, in the overall sample, whereas it only varies from $78.8 \%$ to $100 \%$ and $81.8 \%$ to $100 \%$, respectively, in MDCs. ${ }^{4}$ Finally, in model 4 , both the fertility rate and the prevalence of HIV are associated with an increase of the CIWB in LDCs, as they are both associated with lower life expectancies.

\footnotetext{
4 In the reported models only GDP per capita and exports as a percent of GDP are logged, as it is standard practice to $\log$ some variables that have high skew while having other variables in the model that are unlogged. As a sensitivity analysis, however, I also run elasticity models in which every variable in the model is logged. The models are substantively similar with the only substantive difference being that in the elasticity models for all three groups of countries, exports as a percent of GDP is no longer significant. These sensitivity analyses are available upon request.

I also address potential multicollinearity in the reported models in another set of sensitivity analyses. An examination of variance inflation factors indicated potential multicollinearity when the percent of the population with access to improved sanitation was included in the models. I dropped this variable and re-ran the models and found the results were substantively similar. The only difference was that for the subset of MDCs the percent of the population with access to water and the percent of the urban population with access to improved sanitation were no longer significant. After making this change the mean VIF for the year 2011 was an acceptable 4.43. These sensitivity analyses are available upon request.
} 


\section{Discussion and conclusion}

The results presented here align with previous research results suggesting the impacts of urbanization are not monolithic (Jorgenson, Auerbach, \& Clark, 2014). I find that urbanization has a positive (i.e., undesirable) effect on the CIWB overall, but when separated out by level of development, it has a nonsignificant or negative effect in LDCs. However, the results also reveal the general pattern that urban development is associated with an increase in the CIWB, as indicated by the percent of the urban population with access to improved water and sanitation being associated with a higher CIWB. This finding substantiates concerns that if urban areas continue to follow traditional development models, it may result in some population well-being gains (such as increases in life expectancy), which can reduce the CIWB, but it will likely ultimately be detrimental to the health of the planet and consequently the planet's inhabitants (Jorgenson, 2014). In other words, even if this form of urbanization is a path to development, if it follows the same process as urbanization in MDCs, it will not be sustainable.

Conversely, the presence of urban slums, while highly problematic, does have the desirable consequence of being associated with a reduction in the CIWB. Both justice concerns and logic suggest that we as a global community need to find ways to meet the development needs of all urban dwellers, including those living in slums (Sen, 1999). The current situation of underconsumption, where people are not able to meet basic needs with dignity while elsewhere others are able to overconsume, has negative impacts on social welfare and is unacceptable (Jorgenson, Rice, \& Clark, 2010; Rice, 2008). Yet policies to address underconsumption must also be sustainable, meaning they must decrease the CIWB, and they must not increase carbon emissions beyond certain thresholds (Steinberger \& Roberts, 2010). Furthermore, more developed countries must find ways to reduce their CIWBs. Sustainable development requires change in both less and more developed countries (Steinberger et al., 2013). In considering ways to build upon the results from this paper, I conclude by reviewing some of the literature on meeting the sustainable development needs of urban slum dwellers; such a review might also provide insights into alternative paths of development in multiple contexts (Lamb et al., 2014).

The non-significant and even negative findings for urbanization in general for LDCs suggest that if population needs can be met for slum dwellers using means that retain low emissions, this could be a way forward for sustainable development. While being especially cautious not to fall into the trap of absurd optimism that has led to such travesties as relabeling slums "Strategic LowIncome Urban Management Systems," which Davis (2007, p. 179) ridicules, we may consider policies and programs that might result in the socially and 
environmentally desirable outcome of having percent of urban residents with access to improved water and sanitation have a negative effect on the CIWB. In other words, what can we learn from slums, which are associated with a reduction in the $\mathrm{CIWB}$, to improve well-being without proportional environmental degradation?

Although not all slums are the same and some are characterized by somewhat more sprawling, lower-density development compared to other slums, slums tend to be low income and high density, two qualities that have been found to be more sustainable than other alternatives (Stein, 2009). Steinberger et al. (2012) find that low carbon emissions are not compatible with high incomes at the country level and Jorgenson (2015) finds that reducing population inequality has a negative effect on the CIWB. Attention to density may also be addressed in more or less sustainable ways. For example, some research finds that increasing numbers of households may result in less sustainable outcomes than population increase alone (Cramer, 1997, 1998; Liu et al., 2003).

The results here also show overall population access to improved water and sanitation is associated with a reduction in the CIWB, indicating that meeting human needs is not inherently unsustainable. This draws attention to rural population dynamics and rural-urban linkages as part of sustainable development (Rees, 1992; Tacoli, 2003). This also relates to the findings of Jorgenson (2015) on reducing inequality.

In addressing human well-being issues and sustainability in urban settings a way forward may be to focus on current strengths rather than promoting traditional or imported models of economic development that are associated with increasing $\mathrm{CO}_{2}$ emissions. Sachs (2015), in his suggestions for sustainable development, highlights the creation of the new Sustainable Development Goals and the need for international aid and assistance. While such attention by the global community is vital, Davis (2007) is critical of reliance on general economic development and market-based attempts to address urban poverty, such as methods advocated by De Soto (2000) that promote microcredit, land titling, and the free market. One interesting and specific problematic result of marketbased development policies is described in a study of urban food vendors in Mozambique; the study finds that as men enter markets traditionally dominated by women, the women are driven from certain professions, are economically marginalized, and experience competition that undermines their ability to work collectively (Companion, 2010). This example elucidates two points. First, urban sustainable development strategies cannot be gender-blind (Davis, 2007; Rice, 2008). Second, traditional development strategies that foster competition can undermine some of the strengths that lower-income communities are sometimes found to have. 
Globally, lower-income communities have been found to use social capital as a strategy for resilience (Portes, 1998). Research finds that lower-income neighborhoods in Brazil, including favelas, have higher social cohesion (Villareal \& Silva, 2006), social capital among slum dwellers in Dhaka help them deal with natural hazards, although social capital alone does not enable long-term development (Aßheuer et al. 2013), and development strategies can increase social capital, such as those that foster group participation in urban agriculture (Gallaher et al., 2013). While remaining cognizant that social capital can have negative effects (Portes, 1998), fostering social capital may be one part of a strategy for a resilient relationship between urban society and the environment (Folke, 2006).

People in communities also tend to have a better understanding of the actual needs of their community. Satterthwaite (2001) notes that much international aid is only as effective as the local governments and organizations that are funded to actually implement programs, and therefore developing strong community organizations that have the capacity to achieve effective results is a vital part of addressing urban poverty in LDCs. Groups such as Slum Dwellers International focus on female community savings groups as a means to empower women to learn to manage money, and on projects related to investments in community infrastructure (Patel et al., 2001). Burra et al. (2003) detail successes that local urban groups in India have had with community toilets. Community groups have an understanding of local needs and can focus on building community strengths, partnering with local or international non-governmental organizations, garnering and managing aid, implementing projects, and empowering local residents, which also reduces stigma and builds resilience.

Meeting the needs of urban slum dwellers is a global sustainable development challenge. Without forgetting or neglecting the deprivation that is present in many situations of urban poverty in LDCs, sustainable development strategies might also concentrate on what can be learned from situations that already are associated with reductions in the CIWB, such as urban slums. Insights from this study and related research indicate that strategies to reduce the CIWB include reducing inequality, promoting low-income and high-density living, increasing social capital, and fostering community resilience. Such strategies might also be considered in different contexts to lower CIWB in MDCs. Future research should explore such different pathways to sustainable development and lower CIWBs, attend to the role of gender in urbanization and the CIWB, and continue to examine the links between different forms of urban development and the CIWB and how this might vary regionally and over time. 


\section{References}

Aßheuer, T., Thiele-Eich, I., \& Braun, B. (2013). Coping with the impacts of severe flood events in Dhaka's slums - the role of social capital. Erdkunde, $21-35$.

Amnesty International. (2012). Speaking up from the slums. www.amnesty.org/ en/latest/news/2012/04/speaking-slums/, accessed June 21, 2015.

Beck, N., \& Katz, J. N. (1995). What to do (and not to do) with time-series crosssection data. American Political Science Review, 89(3), 634-647.

Burra, S., Patel, S., \& Kerr, T. (2003). Community-designed, built and managed toilet blocks in Indian cities. Environment and Urbanization, 15(2), 11-32.

Chase-Dunn, C. (1975). The effects of international economic dependence on development and inequality: A cross-national study. American Sociological Review, 720-738.

Companion, M. (2010). Commodities and competition: The economic marginalization of female food vendors in northern Mozambique. WSQ: Women's Studies Quarterly, 38(3), 163-181.

Cramer, J. C. (1997). A demographic perspective on air quality: Conceptual issues surrounding environmental impacts of population growth. Human Ecology Review, 3, 191-196.

Cramer, J. C. (1998). Population growth and air quality in California. Demography, 35, 45-56.

Davis, M. (2007). Planet of Slums. New York: Verso.

De Soto, H. (2000). The Mystery of Capital. New York: Basic Books.

Dietz, T., Frey, R. S., \& Kalof, L. (1987). Estimation with cross-national data: Robust and nonparametric methods. American Sociological Review, 52, 380-390.

Dietz, T., \& Jorgenson, A. (Eds.) (2013). Structural Human Ecology. Pullman, WA: Washington State University Press.

Dietz, T., Kalof, L., \& Frey, R. S. (1991). On the utility of robust and resampling procedures. Rural Sociology, 56, 461-474.

Dietz, T., Rosa, E. A., \& York, R. (2009). Environmentally efficient well-being: Rethinking sustainability as the relationship between human well-being and environmental impacts. Human Ecology Review, 16(1), 114-123. 
Dietz, T., Rosa, E. A., \& York, R. (2012). Environmentally efficient well-being: Is there a Kuznets curve? Applied Geography, 32(1), 21-28.

Evans, P. B., \& Timberlake, M. (1980). Dependence, inequality, and the growth of the tertiary: A comparative analysis of less developed countries. American Sociological Review, 531-552.

Fazal, S. (2000). Urban expansion and loss of agricultural land - a GIS based study of Saharanpur City, India. Environment and Urbanization, 12(2), 133-149.

Folke, C. (2006). Resilience: The emergence of a perspective for social-ecological systems analyses. Global Environmental Change, 16(3), 253-267.

Firebaugh, G. (1979). Structural determinants of urbanization in Asia and Latin America, 1950-1970. American Sociological Review, 199-215.

Gallaher, C. M., Kerr, J. M., Njenga, M., Karanja, N. K., \& WinklerPrins, A. M. (2013). Urban agriculture, social capital, and food security in the Kibera slums of Nairobi, Kenya. Agriculture and Human Values, 30(3), 389-404.

Goldemberg, J., Johansson, T. B., Reddy, A. K., \& Williams, R. H. (1985). Basic needs and much more with one kilowatt per capita. Ambio, 190-200.

Jorgenson, A. K. (2011). Carbon dioxide emissions in Central and Eastern European Nations, 1992-2005: A test of ecologically unequal exchange theory. Human Ecology Review, 18(2), 105.

Jorgenson, A. K. (2014). Economic development and the carbon intensity of human well-being. Nature Climate Change, 4(3), 186-189.

Jorgenson, A. K. (2015). Inequality and the carbon intensity of human wellbeing. Journal of Environmental Studies and Sciences, 1-6.

Jorgenson, A. K., Alekseyko, A., \& Giedraitis, V. (2014). Energy consumption, human well-being and economic development in central and eastern European nations: A cautionary tale of sustainability. Energy Policy, 66, 419-427.

Jorgenson, A. K., Auerbach, D., \& Clark, B. (2014). The (De-) carbonization of urbanization, 1960-2010. Climatic Change, 127(3-4), 561-575.

Jorgenson, A. K., \& Dietz, T. (2015). Economic growth does not reduce the ecological intensity of human well-being. Sustainability Science, 10(1), 149156.

Jorgenson, A. K., \& Givens, J. (2015). The changing effect of economic development on the consumption-based carbon intensity of well-being, 1990-2008, PLOSone, 1-14. 
Jorgenson, A. K., \& Rice, J. (2010). Urban slum growth and human health: A panel study of infant and child mortality in less-developed countries, 1990-2005. Journal of Poverty, 14(4), 382-402.

Jorgenson, A. K., Rice, J., \& Clark, B. (2010). Cities, slums, and energy consumption in less developed countries, 1990 to 2005. Organization \& Environment, 23(2), 189-204.

Jorgenson, A., Rice, J., \& Clark, B. (2012). Assessing the temporal and regional differences in the relationships between infant and child mortality and urban slum prevalence in less developed countries, 1990-2005. Urban Studies, 49(16), 3495-3512.

Kasarda, J. D., \& Crenshaw, E. M. (1991). Third world urbanization: Dimensions, theories, and determinants. Annual Review of Sociology, 467-501.

Kentor, J. (1981). Structural determinants of peripheral urbanization: The effects of international dependence. American Sociological Review, 201-211.

Knight, K. W., \& Rosa, E. A. (2011). The environmental efficiency of well-being: A cross-national analysis. Social Science Research, 40(3), 931-949.

Lamb, W. F., Steinberger, J. K., Bows-Larkin, A., Peters, G. P., Roberts, J. T., \& Wood, F. R. (2014). Transitions in pathways of human development and carbon emissions. Environmental Research Letters, 9(1), 014011-014020.

Liu, J., Daily, G .C., Ehrlich, P. R., \& Luck, G. W. (2003). Effects of household dynamics on resource consumption and biodiversity. Nature, 421, 530-533.

Liu, J., Dietz, T., Carpenter, S. R., Folke, C., Alberti, M., Redman, C. L., Schneider, S. H., Ostrom, E., Pell, A. N., Lubchenco, J., Taylor, W. W., Ouyang, Z., Deadman, P., Kratz, T., \& Provencher, W. (2007). Coupled human and natural systems. AMBIO: A Journal of the Human Environment, 36(8), 639-649.

Liu, Y. S., Wang, J. Y., \& Long, H. L. (2010). Analysis of arable land loss and its impact on rural sustainability in Southern Jiangsu Province of China. Journal of Environmental Management, 91(3), 646-653.

London, B. (1987). Structural determinants of third world urban change: An ecological and political economic analysis. American Sociological Review, 28-43.

Mazur, A. (2011). Does increasing energy or electricity consumption improve quality of life in industrial nations?. Energy Policy, 39(5), 2568-2572.

Mazur, A., \& Rosa, E. (1974). Energy and life-style. Science, 186(4164), 607-610. 
Molotch, H. (1976). The city as a growth machine: Toward a political economy of place. American Journal of Sociology, 309-332.

Morinière, L. (2012). Environmentally influenced urbanisation: Footprints bound for town? Urban Studies, 49(2), 435-450.

O'Connor, J. (1988). Capitalism, nature, socialism: A theoretical introduction. Capitalism, Nature, Socialism, 1, 11-38.

Patel, S., Burra, S., \& d'Cruz, C. (2001). Slum/shack dwellers international (SDI)foundations to treetops. Environment and Urbanization, 13(2), 45-59.

Portes, A. (1998). Social capital: Its origins and applications in modern sociology. Annual Review of Sociology, 24, 1-24.

Preston, S. H. (1979). Urban growth in developing countries: A demographic reappraisal. Population and Development Review, 195-215.

Rees, W. E. (1992). Ecological footprints and appropriated carrying capacity: What urban economics leaves out. Environment and Urbanization, 4(2), 121-130.

Rice, J. (2008). Material consumption and social well-being within the periphery of the world economy: An ecological analysis of maternal mortality. Social Science Research, 37(4), 1292-1309.

Rice, J., \& Rice, J. S. (2009). The concentration of disadvantage and the rise of an urban penalty: Urban slum prevalence and the social production of health inequalities in the developing countries. International Journal of Health Services, 39(4), 749-770.

Rice, J., \& Rice, J. S. (2012). Debt and the built urban environment: Examining the growth of urban slums in the less developed countries, 1990-2010. Sociological Spectrum, 32(2), 114-137.

Rosa, E. A., \& Dietz, T. (2012). Human drivers of national greenhouse-gas emissions. Nature Climate Change, 2(8), 581-586.

Sachs, J. D. (2015). The Age of Sustainable Development. New York: Columbia University Press.

Sanderson, M. R. (2009). Globalization and the environment: Implications for human migration. Human Ecology Review, 16(1), 93.

Satterthwaite, D. (2001). Reducing urban poverty: Constraints on the effectiveness of aid agencies and development banks and some suggestions for change. Environment and Urbanization, 13(1), 137-157. 
Schnaiberg, A. (1980). The Environment: From Surplus to Scarcity. New York: Oxford University Press.

Sen, A. (1999). Development as Freedom. New York: Anchor Books.

Shandra, J. M., London, B., \& Williamson, J. B. (2003). Environmental degradation, environmental sustainability, and overurbanization in the developing world: A quantitative, cross-national analysis. Sociological Perspectives, 46(3), 309-329.

Smith, D. A. (1996). Third World Cities in Global Perspective. Boulder: Westview Press.

Smith, D. A., \& London, B. (1990). Convergence in world urbanization? A quantitative assessment. Urban Affairs Review, 25(4), 574-590.

Stein, K. (2009). Understanding consumption and environmental change in China: A cross-national comparison of consumer patterns. Human Ecology Review, 16(1), 41 .

Steinberger, J. K., Krausmann, F., Getzner, M., Schandl, H., \& West, J. (2013). Development and dematerialization: An international study. PLOSone 8(10), $1-11$.

Steinberger, J. K., \& Roberts, J. T. (2010). From constraint to sufficiency: The decoupling of energy and carbon from human needs, 1975-2005. Ecological Economics, 70(2), 425-433.

Steinberger, J. K., Roberts, J. T., Peters, G. P., \& Baiocchi, G. (2012). Pathways of human development and carbon emissions embodied in trade. Nature Climate Change, 2(2), 81-85.

Tacoli, C. (2003). The links between urban and rural development. Environment and Urbanization, 15(1), 3-12.

Timberlake, M., \& Kentor, J. (1983). Economic dependence, overurbanization, and economic growth: A study of less developed countries. The Sociological Quarterly, 24(4), 489-507.

Villarreal, A., \& Silva, B. F. (2006). Social cohesion, criminal victimization and perceived risk of crime in Brazilian neighborhoods. Social Forces, 84(3), 1725-1753.

Williamson, J. G. (1988). Migrant selectivity, urbanization, and industrial revolutions. Population and Development Review, 287-314.

World Bank, World Development Indicators. databank.worldbank.org/data/ home.aspx, accessed July 24 and September 4, 2014. 
World Resources Institute's CAIT 2.0 climate data explorer. www.cait2.wri.org, accessed August 2, 2014.

United Nations Human Settlements Program (UN-HABITAT). (2003). Slums of the World: The Face of Urban Poverty in the New Millennium? London: Earthscan. www.unhabitat.org, accessed June 21, 2015.

UN-HABITAT. (2006). State of the World's Cities Report 2006/2007. London: Earthscan. www.unhabitat.org and www.unhabitat.org/mediacentre/ documents/sowcr2006/SOWCR\%205.pdf, accessed June 21, 2015.

UN-HABITAT. (2012). State of the World's Cities Report 2012/2013: Prosperity of Cities. World Urban Forum Edition. www.sustainabledevelopment.un.org/ content/documents/745habitat.pdf, accessed June 21, 2015.

UN-HABITAT. (2015a). Housing \& slum upgrading. unhabitat.org/urban-themes/ housing-slum-upgrading/, accessed June 21, 2015.

UN-HABITAT. (2015b). UN-Habitat at a glance. www.unhabitat.org/un-habitatat-a-glance/, accessed June 21, 2015. 
This text is taken from Human Ecology Review, Volume 22, Number 1, 2015, published 2015 by ANU Press, The Australian National University, Canberra, Australia. 